DERLEME MAKALE

\title{
Uyku Kalitesinin Kadın Fertilitesi Üzerine Etkileri ve Uyku Kalitesi Değerlendirme Örneği
}

\author{
Merlinda ALUŞ TOKAT ${ }^{1}$, (Did Figen YANIK ${ }^{2}$
}

${ }^{1}$ Doç Dr., Dokuz Eylül Üniversitesi, Hemşirelik Fakültesi, Doğum ve Kadın Hastalıkları Hemşireliği Anabilim Dalı, İzmir, Türkiye.

${ }^{2}$ Arş. Gör. Dokuz Eylül Üniversitesi, Hemşirelik Fakültesi, Doğum ve Kadın Hastalıkları Hemşireliği Anabilim Dalı, İzmir, Türkiye.

\section{Öz}

Temel yaşam gereksinimlerinden biri olan uyku; kadın sağlığının önemli bir belirleyicisi olarak giderek daha fazla önem kazanmaktadır. Son yıllarda literatürde fertilitenin kadının uyku süresinden ve kalitesinden etkilenip etkilenmediği üzerinde durulmaktadır. Kaliteli uyku fertilite ile ilgili hormonlar da dahil olmak üzere; vücudumuzda görev alan hormonları düzenlemeye ve hasarlı hücrelerin yenilenmesine yardımcı olmaktadır. Fertilite dahil olmak üzere, birçok fizyolojik ve psikolojik olaylar içeren uyku; infertil çiftlerin tedavi sürecinin daha olumlu bir yön bulmasına katkı sağlayabilir. Zorlu tedavi sürecinde iyi bir uyku kalitesine sahip olmak; hem kadına mevcut stresiyle başa çıkması konusunda daha iyi hissettirebilir, hem de kadının sağlıklı oosit üretimine yardımcı olabilir.

Bu derlemenin amacı; uykunun fertiliteyi ne derece ve hangi mekanizmalarda etkileyebildiğini açıklamak, böylece ülkemizde fertilite alanında çalışan hemşireler/sağlık profesyonelleri için bir farkındalık oluşturmaktır. Hemşireler, uykunun fertilite sürecinde önemini anlayarak, infertil çiftlerin değerlendirilmesinde çiftlerin yaşam tarzlarını incelemelerinin önemini kavrayacaklardır. Ayrıca hemşirelerin bu süreçte izleyebilecekleri değerlendirme örneğinin bu alanda çalışan hemşireler/sağlık profesyonelleri için yol gösterici olması amaçlanmıştır..

Anahtar Sözcükler: Uyku, İnfertilite, Sirkadiyen Ritim, Üreme Sağlığı, Kadın Sağlı̆̆ı.

\section{The Effects of Sleep Quality on Female Fertility and an Example for the Assessment of Sleep Quality}

Sleep, one of the basic life needs; It is becoming increasingly important as an important determinant of women's health. Recently in the current literature; It is focused on whether fertility is affected by the woman's sleep time and quality. Quality sleep, including hormones related to fertility; It helps regulate the hormones involved in our body and regenerate damaged cells. Sleep involving many physiological and psychological events, including fertility; it can contribute to the infertile couples' finding a more positive direction . Having a good sleep quality during the difficult treatment process; it can both make the woman feel better at dealing with her current stress and help the woman produce healthy oocytes.

The purpose of this review is; explaining to what extent sleep can affect fertility and in which mechanisms, thus creating an awareness for nurses / health professionals working in the field of fertility. By understanding the importance of sleep in the fertility process, nurses will comprehend the importance of examining couples' lifestyle in the evaluation of infertile couples. In addition, it is aimed to guide the nurses / health personnel working in the field by creating an evaluation example that they can follow in this evaluation.

Key Words: Sleep, Infertility, Circadian Rhythm, Reproductive Health, Women's Health.

Geliş Tarihi / Received: 18.08.2020 Kabul Tarihi / Accepted: 05.03.2021

Correspondence Author: ${ }^{2}$ Arş. Gör. Dokuz Eylül Üniversitesi, Hemşirelik Fakültesi, Doğum ve Kadın Hastalıkları Hemşireliği Anabilim Dalı, İzmir, Türkiye Telefon: +90 2324124792 E-posta: figen.satkan@gmail.com

Cite This Article: Aluş Tokat M, Yanık F. Uyku Kalitesinin Kadın Fertilitesi Üzerine Etkileri ve Uyku Kalitesi Değerlendirme Örneği Dokuz Eylül Üniversitesi Hemşirelik Fakültesi Elektronik Dergisi. 2021; 14(3): 253- 260 
i nfertilite yaşam kalitesini azaltan ciddi bir sağlık sorunudur (1). Dünya Sağlık Örgütü verilerine göre, infertilite üreme çağındaki çiftlerin \%15'ini etkilemektedir. Ülkemizde de yaklaşık olarak 1,5-2 milyon kişinin infertilite sorunu ile karşı karşıya olduğu ve sorunun giderek arttığı belirtilmektedir (2). Günümüzde ileri teknolojik gelişmeler sonucunda infertilite tedavisinde başarı giderek artmaktadır. Klinik uygulamalarda infertilite sürecindeki teknolojik ve tedavi gelişmeler çok fazla ön planda iken, infertilite sorunu yaşayan çiftlerin yaşam tarzı çok ayrıntılı değerlendirilmemekte ve iyileştirilmemektedir. Dünya literatüründe ise son yıllarda infertilitede yaşam tarzı faktörleri üzerinde durulmaktadır. Aslında infertilite oranlarının giderek artmasının en büyük etkenlerinden biri; yaşam tarzımızın olumsuz etkileri olduğu düşünülmektedir (3). Yaşam tarzı faktörleri, fertilite dahil olmak üzere genel sağlık ve refahı büyük ölçüde etkileyebilecek değiştirilebilir alışkanlıklar ve yaşam şekilleridir. Fertiliteye etki eden beslenme, fiziksel aktivite gibi diğer yaşam tarzı faktörleri ile karşılaştıııldığında; uyku ve fertilite arasındaki ilişki hakkında çok az şey bilinmektedir (4). Çocuk sahibi olmak için yaşanan bu süreçte çiftler stres yaşayabilmekte ve stresin sonucunda da yaşam tarzları değișebilmektedir. Stres kişilerin beslenmesini, uyku alışkanlığını, fiziksel aktivitesini ve sonuç olarak fertilite tedavisinin başarısını etkileyebilmektedir. Özellikle infertilite tedavi sürecinin uykuya etkisi çok yeni ve önemli bir konudur. Kadınlar infertilite tedavi sürecinde kullanılan ilaçlar etkisi ile hormonal değişikliklere maruz kalmakta ve bu hormonal değişiklikler kadınlarda bazı şikayetlere sebep olmaktadır. Sonuçta bu şikayetler kadınlarda psikolojik sıkıntı yaratmakta ve uyku problemlerine neden olabilmektedir. Lin ve arkadaşları (5) intrauterin inseminasyon tedavisi gören 117 infertil kadında uyku kalitesini araştırmak ve uyku bozukluğuna neden olan faktörleri incelemek amacıyla yaptıkları çalışmada; kadınların \% 35'inin uyku bozukluğu yaşadığını bildirmişlerdir. Ayrıca kadınlarda hormonal değişimlere bağlı olarak bulantı, kusma, yorgun hissetme, psikolojik sıkıntı gibi belirtiler görülmüştür. Bulantı belirtileri ve psikolojik sıkıntı, uyku bozukluğuna katkıda bulunan risk faktörleri olarak belirlenmiştir. Aynı yazarların (6) yaptığı benzer bir çalışmada ise; oosit pick up (OPU) ve embriyo transferi (ET) tedavileri zamanlarında 100 kadının uyku durumu değerlendirilmiştir. Kadınların bu süreçte; abdominal distansiyon, memelerde dolgunluk ve yorgunluk gibi belirtilerin yaşadıklarını belirtmişlerdir. Fakat uyku sorunları incelediğinde OPU sürecine kadar kadınların \% 23'ünde, ET sonrası kadınların \%45'sında uyku bozukluğu görüldüğü saptanmıştır. Özetle, ET sonrasında OPU işlemine kadar olan süreye göre kadınlarda daha yüksek oranda fiziksel belirtiler görülmüş ve bu sebeple ET sonrası kadınların daha fazla uyku problemleri yaşadıkları belirtilmiş̧ir. Goldstein ve arkadaşları (7) 22 kadında uykunun sübjektif ve objektif verilerini; over uyarımı başlamadan önce, kontrollü over uyarımı sırası ve embriyo transferi sonrası-gebelik testi öncesi olmak üzere toplam üç dönemde kaydetmiştir. Sonuçta; kadınların over stimulasyon sürecindeki uyku kalitesinin daha iyi olduğu ve embriyo transferi sırasında daha çok uyku sorunları yaşadıkları görülmüştür. Ayrıca uyku süresindeki bir saatlik artışı; elde edilen oosit sayısını olumlu yönde etkilediği bulunmuştur.

Sınırlı literatürden de anlaşıldığı gibi kadınlar tedavi sürecinde uyku sorunları yaşamakta ve bu sorunlar özellikle embriyo transfer sürecinden sonra da daha belirginleşmektedir. Sağlık profesyonelleri olarak infertilite merkezlerine başvuran kadınların genel sağlık durumunu etkileyen önemli belirteçlerden biri olan uykuyu ne kadar değerlendiriyoruz? Uyku sorunların yaşandığ 1 bu tedavi sürecinde fertilite sonuçlarına etkisini ortaya koymak; kliniklerde bu yaşam tarzı komponentinin daha iyi değerlendirilmesini ve tedavi sürecini iyileştirmek için girişim planlanmasını sağlayabilir. Bu nedenlerle; derlemenin amacı uyku süresini ve kalitesinin kadın fertilitesi üzerine etkisi ortaya koymak ve hemşireler için uygun bir değerlendirme örneği oluşturmaktır.

\section{Gelişme}

\section{Uykunun Üreme Sağlı̆̆ına ve Fertiliteye Olası Etkisi}

İnfertilite kapsamlı bir konudur ve oksidatif stres gibi farklı faktörler infertiliteye neden olabilmektedir. Ovulasyon sürecinde makrofajlar, nötrofiller ve parankimal hücreler tarafindan reaktif oksijen türevleri üretilmektedir. Reaktif oksijen türevleri temelde hücreler için zararlı olan metabolitlerdir ve oositler gelişim sürecinde bu zararlı metabolitlere maruz kalabilmektedir. Fakat oositlerin maruz kaldığı zararlı metabolitlere rağmen sağlıklı oosit ve embriyolar oluşturabilmektedir. (8) Uyku kadının oositlerini ve fertilitesini etkileyebilen önemli yaşam tarzı belirleyicisi olduğu düşünülmektedir. Ulusal Uyku Kuruluşu'nun (9) 2015 yılında yayınladığı kanıta dayalı rapora göre genç yetişkinlerin (18-25 yaş) ve yetişkinlerin (26-64) ortalama uyku süresinin 7-9 saat olarak bildirilmiştir. Ayrıca bu yaş grubu bireylerin 11 saatten fazla, 6 saatten az uyumamaları gerektiği raporda belirtilmiştir. Sağlı̆̆ımız için oldukça önemli olan uyku döngüsü; REM, NREM ve uyanıklık arasında devam eden süreçtir. İşte bu uyku uyanıklı döngüsü içerisinde sirkadiyen ritim gerçekleşmektedir (10). Sirkadiyen; yaklaşı anlamına gelen "circa" ve gün anlamına gelen "dies" olmak üzere latince iki kelimeden oluşan ve "yaklaşık bir günü" ifade etmek için kullanılan terimdir. Vücudumuz sirkadiyen ritim denilen iç saat tarafindan kontrol edilmektedir. Sirkadiyen ritim; organizmanın yaklaşık bir günlük fizyolojik ve biyolojik değişimlerini ifade eder (11). Sirkadiyen ritmi düzenleyen ana merkez; hipotalamusun ön kısmında bulunan suprakiazmik nükleus $(\mathrm{SCN})$ adı verilen bir yapıdır. Vücudumuzun uyku-uyanıklık döngüsü; büyüme hormonu, kortizol, melatonin gibi bazı hormonların salgılanması suprakiazmik çekirdeğin kontrolündedir (12).

Uykuda salgılanan ve hücre sağlığı için önemli olan büyüme hormonu, hücrelerin çoğalması ve kendi kendini yenilemesine yardımcı olmaktadır. Dolayısıyla büyüme hormonun yeterli salgılanması oosit sağlığını ve fertiliteyi de etkileyebilmektedir. Son zamanlarda özellikle melatoninin antioksidan rolüyle oositleri koruduğu düşünülmektedir (13). Melatonin; biyolojik saat dediğimiz sirkadiyen ritmi ve üreme ile ilgili çeşitli önemli merkezleri etkilemektedir. Gece; karanlık ortamda, 1şık uyarısının yok olması ile birlikte; epifiz bezi uyarılmakta ve melatonin hormonu sentezlenmektedir. Melatonin hormonu kan serumu ile karşılaştırıldığında; insanın preovulatuar foliküler sıvısında daha yüksek konsantrasyonda bulunmuştur (14). Melatoninin doğrudan serbest radikal toplayıcı olarak bulunması, üreme fizyolojisine yarar sağlayan melatonin mekanizmasının anlaşılmasını kolaylaşıırmıştır.

Işık uyarısının etkisi ile suprakiazmik çekirdek uyarılır. Suprakiazmik çekirdeğe aktarılan ışık uyarısı buradan bir takım nöral ağlar aracılığıyla epifiz bezine iletilir. Epifiz bezinin uyarılması ile melatonin hormonu salgısı baskılanır. Gece boyunca karanlık bir ortamda ş̧ık uyarısının yok olmasıyla epifiz bezi tekrar uyarılır ve melatonin hormonu salgılanır. Melatonin kan yoluyla 
overlere geçerek burada bir takım hücresel olaylarda görev alır. Overlere geçen melatonin over içerisinde antioksidan görevi ile oksidatif stresi azaltarak oosit maturasyonunu sağlar ve embriyo gelişimine yardımcı olur. (Şekil 1) Bu sebeple gece uykusu ve melatonin hormonunun yeterli düzeyde salgılanması oosit kalitesi açısından çok önemlidir (12). Suprakiazmik çekirdek kontrolündek bir diğer hormon olan kortizol ise gece uykuda en az seviyede iken, saat geçtikçe artar ve uyanmadan hemen önce en üst seviyeye çıkar. Gece en az seviyedeyken sabah saatlerinde kortizonun artmasının sebebi vücudumuza verilen bir uyanma sinyali olmasıdır. Yeterli uyku durumunda düşük kortizol uyarısında hem over hemde utersu vaskülarizasyonu olumlu yönde etkilenmektedir. Uyku ile ilişkilendirilen bu üç hormonun fertiliteye olası etkisi Şekil-2'de gösterilmiştir.

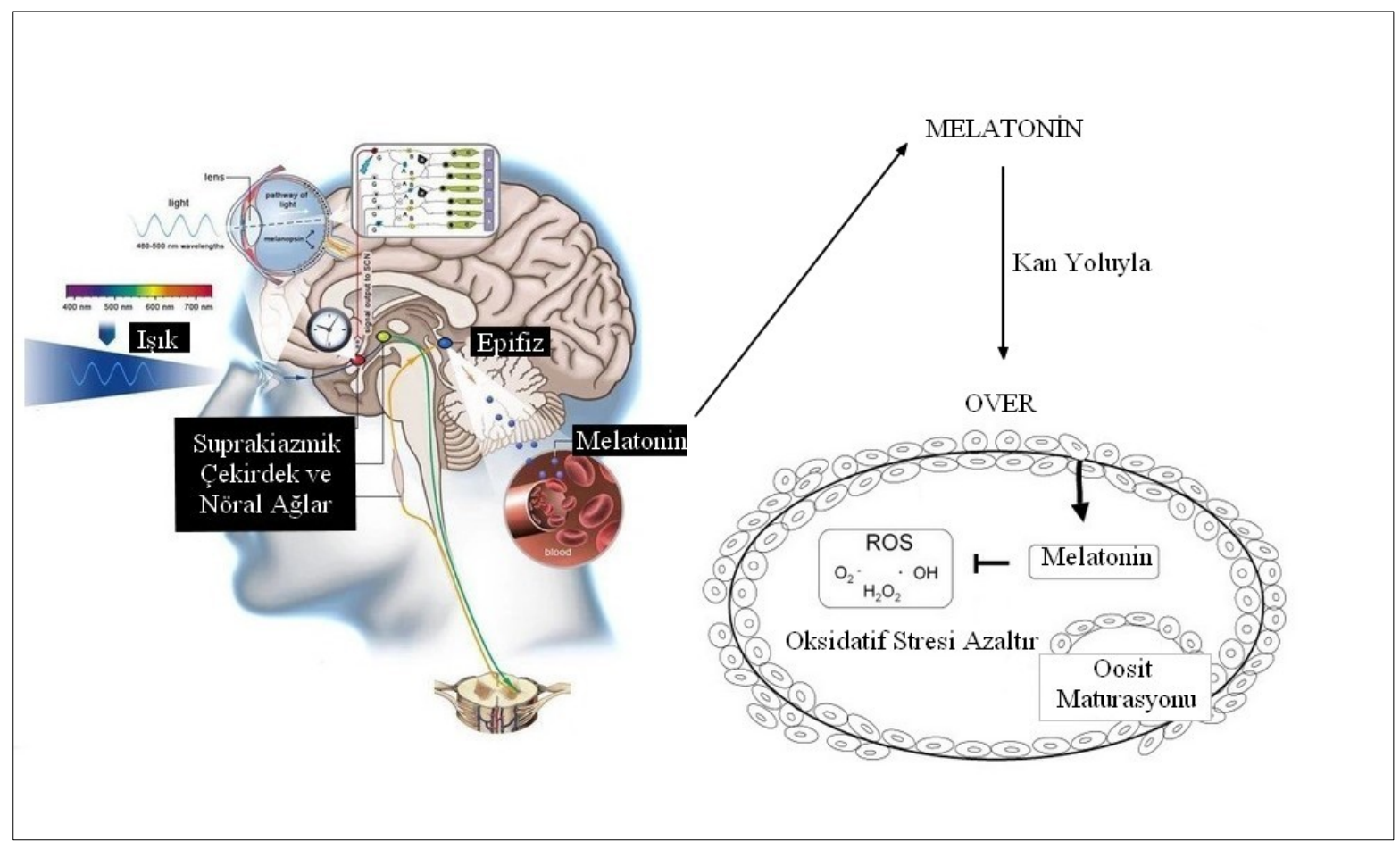

Şekil 1: Folikül Sıvısında Melatonin Hormonu Görevinin Şematik Gösterimi

Kaynak: Tamura H ve arkadaşları 2012.

Günümüzde uyku kalitesini etkileyen en önemli sorunlardan biri de; gece elektronik cihazların ekranlarından yayılan mavi 1şıktır. Bu cihazların ışı̆̆ına maruz kalarak uyumak; gece uyku kalitesini düşürmekte ve uykuya dalma süresini uzatmaktadır (16). Mavi ışığın yaydığı dalgalar uykuda salgılanan melatonin, büyüme hormonu ve kortizol gibi hormonların salınımını etkilemektedir. Melatonin hormonunun salınımı engellenerek/azaltılarak antioksidan rolünün etkisi azaltmaktadır. Zamanla folikül içerisindeki serbest radikal seviyesi artmakta, hücresel hasar meydana gelmekte ve devamında oosit maturasyonu engellenmektedir. Bunun yanısıra stresin temel hormonu olan kortizol; yetersiz uyku durumunda artmaktadır. Stres artınca artan kardiyak out-put sonucunda kan yaşamsal organlara yönelir ve uterusa giden kan akımı azalmaktadır. Böylece uterusa giden hormonal etki de etkilenerek, endometriyal proliferasyonu etkilenebilmektedir. Bu olaylar sonucunda implantasyon için uygun ortamının sağlanmaması ve paralelinde fertilite sorunları yaşanabilmektedir. Ayrıca stres durumunda overlerin vaskülarizasyonu da etkilenerek follikül gelişimi de gecikebilmektedir ve maturasyonu engellenebilmektedir.

Diğer yandan uykuda salınması gereken büyüme hormonunun salınımı etkilenmekte ve hücre çoğalması, yenilenmesi gibi temel hayati olayların gerçekleşmesi önlenmektedir (Şekil 2). Tüm bu durumlar sonucunda fertilite etkilenebilmektedir.

Rad ve arkadaşları (17) yaptıkları çalışmada fertil ve infertil kadınlarda melatonin düzeyi ve oksidatif belirteçler ile ilişkisine bakmışlardır. Fertil ve infertil kadınlar 30 kişilik iki gruba ayrılıp, serumdaki melatonin düzeyleri ve total antioksidan kapasiteyi değerlendirmişlerdir. Sonuçta; fertil kadınlardan alınan serum melatonin ve toplam antioksidan kapasite infertil kadınlara oranla daha yüksek bulunmuştur. Toplam 209 kadının uyku kalitesi ile yardımcı üreme tekniği başarısı arasındaki ilişki incelenen başka bir çalışmada kadınların uyku kalitesi iyi, orta ve kötü olarak değerlendirmiş ve kadınlar üç gruba ayrılmıştır. Yardımcı üreme tekniği (YÜT) ile tedavi gören 209 kadının \%65.1'i iyi uyku kalitesine, \%26.8'i orta ve \%8.1'i kötü uyku kalitesine sahip olduğu belirlenmiştir. Sonuç olarak; iyi uyku kalitesine sahip kadınlarda fertilizasyon ve blastosist gelişimini pozitif yönde etkilediği belirlenmiştir (18). Fertilite tedavisi gören kadınlarda uykunun üreme sağlığı üzerindeki etkisini inceleyen başka bir çalışmada ise; 656 kadının in vitro fertilizasyon (IVF) tedavisine başlamadan önce uyku süreleri değerlendirilmiştir. Kadınlar daha sonra uyku sürelerine göre kısa süreli uyuyanlar (3-6 saat), orta süreli uyuyanlar (7-8 saat) ve uzun süreli uyuyanlar (9-11 saat) olmak üzere üç gruba ayrılmıştır. Oosit sayısı ve fertilizasyon oranının tüm gruplarda benzer olduğu saptanmıştır. Gebelik oranı, orta süreli uyuyanlarda uzun süreli ve kısa süreli uyuyan kadınlara göre anlamlı düzeyde yüksek bulunmuştur (19). Melatonin hormonu etkisine yönelik yapılan başka bir çalışmada ise; uyku bozukluğu olan açıklanamayan infertilite tanısı olan kadınlara oral yoldan melatonin verilip IVF sonuçlarına bakılmıştır. Uyku problemi yaşayan 60 kadın örnekleme alınmış, bir gruba oral melatonin uygulanıp, diğer gruba uygulanmamıştır ve IVF sonuçları 
karşılaştırılmıştır. Melatonin uygulaması yapılan kadınlarda; menstural siklusun 3-5. günlerinden itibaren başlanıp HCG enjeksiyon gününe kadar, günde bir doz oral melatonin uygulanmıştır. Sonuçta; uyku durumu değişikliğinde anlamlı bir değişiklik gözlenmemiştir fakat elde edilen oosit sayısında melatonin uygulanan grupta daha yüksek iken fertilizasyon, implantasyon ve gebelik oranları her iki grupta benzer bulunmuştur. Çalışmada; uyku problemi yaşayan ve IVF tedavisi alan kadınlarda oral melatonin uygulanmasının kadınlarda uyku problemlerini düzeltmeyebileceği ancak oosit kalitesini arttırmak amacıyla kullanılabileceği sonucuna varılmıştır (20).

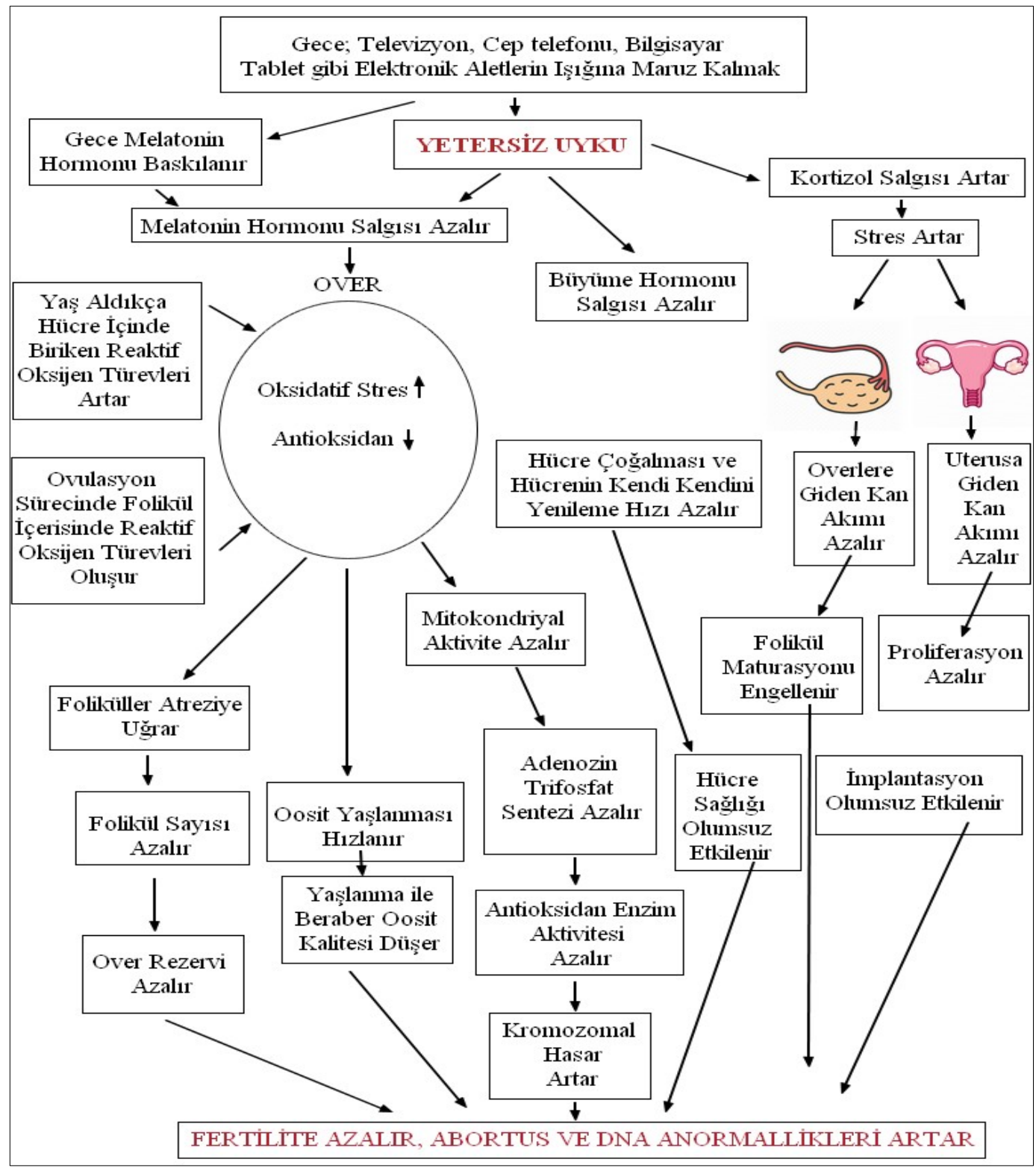

Şekil 2: Yetersiz Uykunun Kadın Fertilitesi Üzerine Olası Etkisi

Kaliteli uyku fertilite ile ilgili hormonlar da dahil olmak üzere; vücudumuzda görev alan hormonları düzenlemeye ve hasarlı hücrelerin yenilenmesine yardımcı olabilmektedir. Böylece oosit kalitesi ve fertiliteyi arttıran önemli bir unsur olabilir (Şekil 3). 


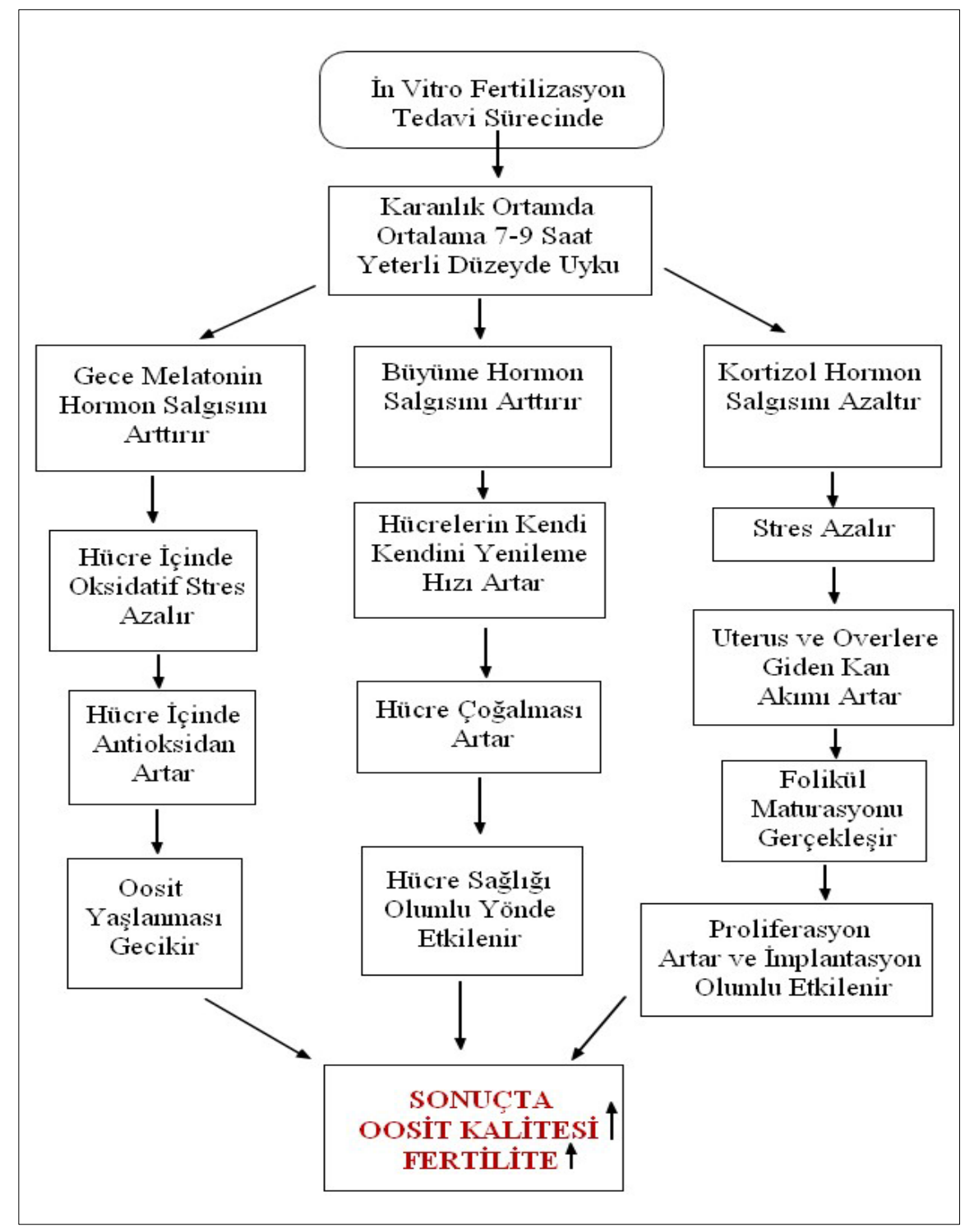

Şekil 3: Kaliteli Uykunun Oosit Kalitesi Ve Fertilite Üzerine Olası Etkisi

İn vitro fertilizasyon tedavisi kadınlara her ne kadar ümit verse de; tekrarlayan invaziv işlemler; kadınlar için duygusal ve fiziksel yük olabilmekte ve bu tedavi sürecinde kadınlar uyku problemleri yaşayabilmektedir. Fertilite dahil olmak üzere, birçok fizyolojik ve psikolojik olaylar içeren uyku; yardımcı üreme tekniği ile tedavi sonuçlarının iyileşmesine katkı sağlayabilir. $\mathrm{Bu}$ nedenle infertilite tedavisi gören kadınların uyku koşullarının iyileştirilmesi; sağlık bakım personellerinin temel hedeflerinden biri olmalıdır. IVF tedavisi alan kadınların rutin olarak uyku kalitesi değerlendirilmeli, uyku ile ilgili problem varsa buna sebep olan faktörleri belirlenmeli ve bunlara yönelik girişimler yapılmalıdır. Kadınların en önemli yaşam tarzı belirleyicilerinden olan uykunun fertilite üzerine olumlu etkisi göz ardı edilmemelidir. Zorlu infertilite tedavi sürecinde iyi bir uyku kalitesine sahip olmak; hem kadına mevcut stresiyle başa çıkması konusunda daha iyi hissettirebilir, hem de kadının sağlıklı oosit üretimine yardımcı olabilmektedir.

\section{Hemşireler ne yapabilir?-Değerlendirme Örneği}

Klinik uygulamada kadınların uyku alışkanlıklarını değerlendirmek ve geliştirmek için hemşire olarak bazı düzenlemeler yapabiliriz.

- Kadınların genel uyku kaliteleri değerlendirilmeli, aynı zamanda gece yatış saati ve sabah uyanış saatleri öğrenilmelidir.

- Uykunun fertilite üzerine olan olası etkileri kadına uygun bir dille açıklanmalıdır; gerekirse görsel ve yazııı materyaller verilmelidir.

- Uyku durumunda bir problem varsa nedeni belirlenmelidir (yatma saati, ışıkta uyuma vb).

- Uyku kalitesinin etkileyen faktörlerin nasıl iyileştirebilir konusunda birlikte plan yapılmalıdır.

- Uygun uyku planı yapılmalıdır.

- Gevşeme gibi rahatlatıcı uygulamalar kadınlara öğretilerek, uykudan önce rahatlaması için öğretilmelidir. 
- Yapay 1şıkların ortamlardaki olumsuz sağlık etkilerini azaltmak için; TV, bilgisayar gibi elektronik aletleri uyumadan birkaç saat önce kapatması ve rahat uyku ortamını hazırlaması söylenmelidir. Gündüz saatlerinde de mavi 1şık filtresi bulunan cihazlar veya gözlük camları kullanılabilir.

- Yatak odasında hiçbir ışık kaynağı ve dijital cihaz bulunmaması gerektiği söylenmelidir.

- Mavi 1şıktan korunmak için mavi ışığa maruz kalma süresi azaltılmalıdır. Uzun saatler (2 saat ve üzeri) bilgisayar, televizyon gibi ekrana maruz kalıyorsa mutlaka 15-20 dk ekrandan uzaklaşıp dinlenmesi gerektiği söylenmelidir.

- Gürültü ve dış ortam ışığına en az maruz kalan odanın yatak odası olarak tercih edilmesi, evcil hayvan besliyorsa uyuduğu odadan çıkarması gibi uykudan yüksek verim alması için önerilerde bulunulmalıdır.

- Biyolojik saatin bir parçası olan uykuyu ve gün ışı̆̆ııı yeterli miktarda almak ve gece uykusunda vücudun hormon dengesine zarar veren yapay ışıklardan uzak durulması için önerilerde bulunulmalıdır. Günlük güneş 1şı̆̆ına bir saat maruz kalmak bile vücudumuzun sirkadiyen ritmini düzenleyip rahat uyku uyumayı sağlayacaktır.

- Gün içindeki kortizol seviyelerinin uyku durumunu etkileyeceği unutulmamalıdır. Yüksek kortizol seviyesinin rahatlamayı ve kaliteli uyku almamayı engellemektedir. Tedavi gören kadına kortizolun ve stresin olumsuz etkileriyle mücadele etmek için; nefes teknikleri, yoga gibi teknikler önerilebilir.

• Gün içinde çok fazla uyumak da uyku döngüsünü bozmaktadır. Kısa şekerlemeler hariç gündüz vakti çok fazla uyumaması, bu süreyi gece uykusuna ayırması söylenmelidir.

- Uyku rutininde tutarlı olmak da önemlidir. Tedavi sürecinde ve sonraki süreçlerde her gün aynı saatte yatıp aynı saatte kalkacak şekilde kendi uyku rutinini oluşturması gerektiği belirtilmelidir.

\section{Tedavi Sürecinde;}

- Kadının uyku durumu hem oosit toplama işlemine kadar hem de embriyo transferinden sonra değerlendirilmeli ve iyileştirmek için öneriler verilmelidir.

- İyi uyku sadece saat sayısına değil, kalitesine de bağlıdır. Bu sebeple kadınların sadece kaç saat uyudukları değil, uykularının kalitesini nasıl değerlendirdikleri de öğrenilmelidir.

- Sorun varsa değerlendirilip kaynağına yönelik girişim yapılmalıdır.

- Kadınlar özellikle embriyo transfer sürecinden sonra gebelik testi beklerken stres düzeyleri artmakta ve bu durum uyku kalitesini olumsuz etkilemektedir. Özellikle embriyo transfer süreci sonrasında uyku durumu değerlendirilmeli; kadınların olumsuz düşüncelerden uzak durmasını sağlayacak rahatlatıcı teknikler öğretilmeli ve uygulanmalıdır.

- Uyku öncesi ağır egzersizler uykuyu bölebilir. Ancak haftada en az 4-5 kere orta düzeyde egzersiz yapmak hem stresi azaltmakta hem de uyku kalitesini arttırmakta, uyku döngüsü arasında geçişleri düzenlemekte ve derin uyku süresini arttırmaktadir.

- Uyumadan en az 4-6 saat önce uyarıcı etkisi bulunan kafein içeren içecekleri kısıtlaması söylenmelidir.

- Uyku öncesi zihinsel kontrolü geliştirmeye yönelik girişimler yapılmalıdır. Özellikle uyku öncesi aksiyon filmi izleme, uzun sohbet, konuşma gibi zihni uyarıcı eylemlerden kaçınılması ile ilgili bilgilendirilmelidir.

- Gece olumsuz düşüncelerden uzaklaştıracak bir diğer nonfarmakolojik yaklaşım olan gevşeme egzersizi ve görsel imgeleme vb. aktiviteler öğretilmelidir.

- Uyumadan önce mümkünse gevşemek amacıyla ılık su ile duş alınması ile ilgili bilgilendirilmelidir.

- İlaç tedavi saatleri uyku durumunu bölmeyecek şekilde planlanmalıdır.

- Hemşirelerin değerlendirme ve girişim için kullanabilecekleri örnek değerlendirme şekil 4'te verilmiştir (Şekil 4). 


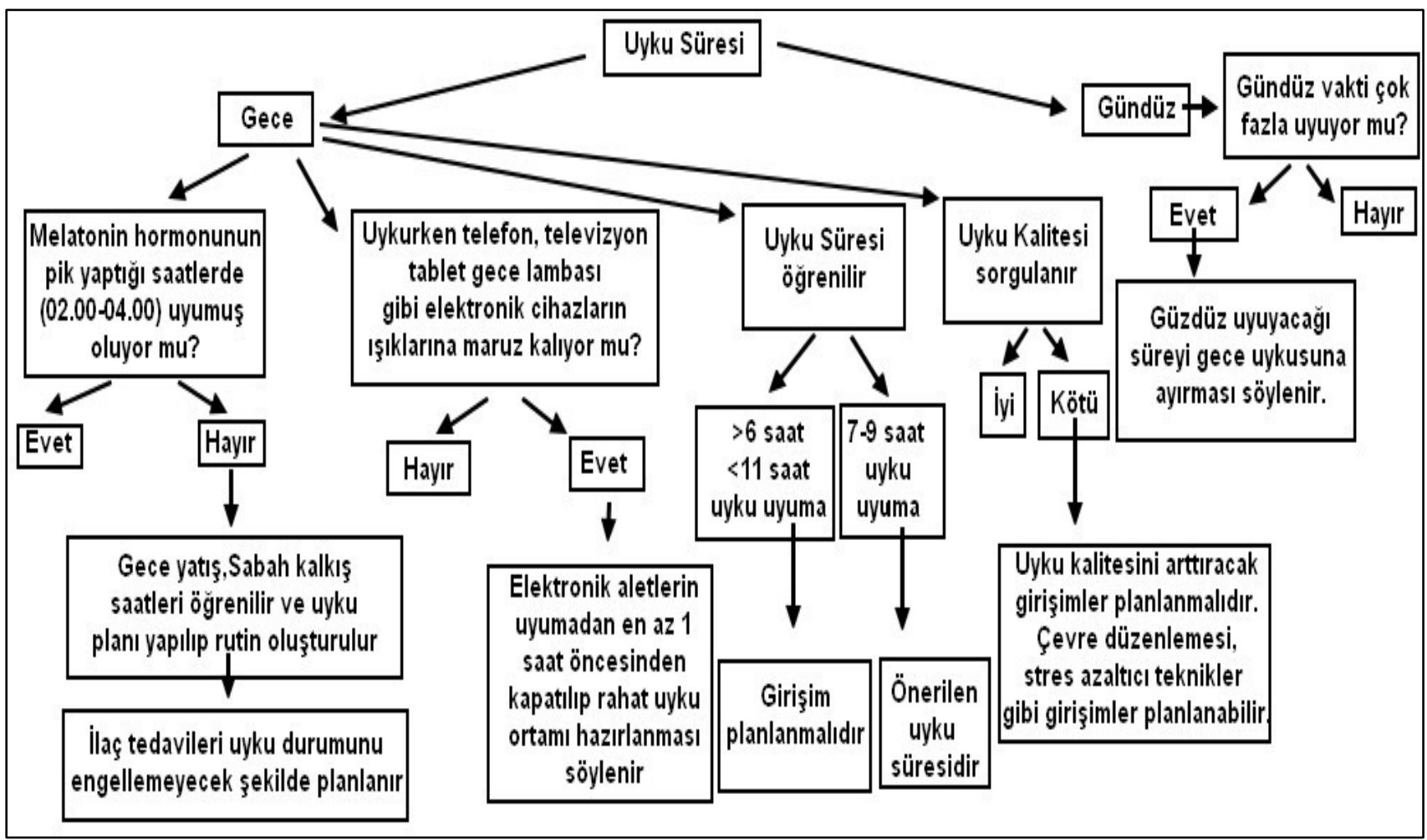

Şekil 4: Hemşireler İçin Değerlendirme Örneği

\section{Sonuç}

1970’li yıllardan bu yana aile dayanıklılığı konusunda teorik bir çerçeve oluşagelmiştir. Bu süreçte bakış açısı hastalıktan sağlığa, Tüm bu incelemeler sonucunda kaliteli uyku fertilite ile ilgili hormonlar da dahil olmak üzere; vücudumuzda görev alan hormonları düzenlemeye ve hasarlı hücrelerin yenilenmesine yardımcı olmaktadır. Yani uykunun fertilite dahil olmak üzere birçok fiyolojik ve psikolojik olaylar içerdiğini görebiliriz. İnfertilite tedavi sürecinin daha olumlu bir yön bulmasında hemşire olarak çiftleri değerlendirirken, çiftlerin yaşam tarzlarını da değerlendirip hangi durumları iyileştirebiliriz diye düşünmemiz gerekmektedir. Çünkü iyi bir uyku kalitesi; kadının zorlu tedavi sürecinde rahatlamasını sağlayabilir, mevcut stresiyle başa çıkma konusunda daha iyi hissedebilir ve sağlıklı oosit üretimine yardımcı olabilir. Tüm bu sonuçlar kadının fertilitesini olumlu etkileyebilir.

Sonuç olarak; kadınların en önemli yaşam tarzı belirleyicilerinden olan uyku ve sonuçları göz ardı edilmemelidir. Hemşire olarak IVF tedavisi alan kadınların rutin olarak; uyku kalitesini değerlendirmeli, uyku bozukluğu varsa buna sebep olan faktörleri belirlemeli ve bunlara yönelik girişimler yapmalıyız.

\section{Bilgilendirme}

$\mathrm{Bu}$ derlemede herhangi bir potansiyel çıkar çatışması bulunmamaktadır. Derlemede araştırma ve yayın etiğine uyulmuştur. Derlemenin hazırlanmasına tüm yazarlar katkıda bulunmuştur. Derlemenin fikir, tasarım, denetleme ve eleştirel incelemesine MAT katkı sağlamıştır. Literatür taraması, fikir ve tasarımı konularında ise FY katkı sağlamıştır. Bu derleme herhangi bir kongrede tam metin veya bildiri olarak yayınlanmamış, daha önce hiçbir dergide yayınlanmamış, yayınlanmak üzere kabul edilmemiş ve değerlendirme altına alınmamıştır. 


\section{Kaynaklar}

1. Speroff L, Fritz M. The gynecologic endocrinology and infertility. 7th Edition. Lippincott Williams \& Wilkins. Philadelphia. 2005. p. 187-224.

2. Amanak K, Karagöz B, Sevil Ü. Effect of the modern life on infertility. TAF Prev Med Bull. 2014; 13(4): 345-350.

3. Sharma R, Biedenharn K, Fedor F, Agarwa A. Lifestyle factors and reproductive health: taking control of your fertility. Reproductive Biology and Endocrinology. 2013; 1477-7827.

4. Piche M, Babineau V, Robitaille J, Lachance E, Ruchat S. Lifestyle-related factors associated with reproductive health in couples seeking fertility treatments: results of pilot study. International Journal of Fertility and Sterility. 2018; 12(1): 19-26

5. Lin J, Lin Y, Chuch K. Somatic symptoms, psychological distress and sleep disturbance among infertile women with intrauterine insemination treatment. Journal of Clinical Nursing. 2014; Jun;23(11-12):1677-84.

6. Lin J, Lin Y, Chuch K. Somatic symptoms, psychological distress and sleep disturbance among women undergoing oocyte pick-up and in vitro fertilization-embryo transfer. Journal of Clinical Nursing. 2016; Jun;25(11-12):1748-56.

7. Goldstein C, Lanham M, Smith Y, O’Brien L. Sleep in women undergoing in vitro fertilization: a pilot study. Sleep Medicine Journal. 2017; 105-113.

8. Tamura H, Nakamura Y, Takiguchi S, et al. Melatonin directly suppresses steroid production by preovulatory follicles in the cyclic hamster, J Pineal Res. 1998; 25: 135-41.

9. Hirshowitz M, Whiton K, Albert SM, Alessi C, Bruni O, DonCarlos L, et al. National sleep foundation's updated sleep duration recommendations: final report. Sleep Health. 2015; 1(4):233-43.

10. Guyton AC, Hall JE. Medical Physiology. 13th edition. USA, 2016. p.689-690.

11. Zee PC, Mantena P. The brain's master circadian clock; implications and opportunities for theraphy of sleep disorders, Sleep Med Rev. 2007; 11:59-70.

12. Gooley JJ, Saper CB. Anatomy of the mammalian circadian system. In Principles and Practice of Sleep Medicine. (Eds MH Kryger, T Roth, WC Dement): 2005; 335-350. Philadelphia: Elsevier Saunders.

13. Agarwal A. Oxidative stress and its implications in female infertility - a clinician's perspective. Reproductive Bio Medicine. 2005;11:641-50.

14. Tamura H, Takasak A, Taketani T, Tanabe M, Kizuka F, Lee L et al. The role melatonin as an antioxidant in the follicle. Journal of Ovarian Research. 2012;5:5

15. M. Figueiro, D. Overington. Self-luminous devices and melatonin suppression in adolescents. Lighting Research\& Technology. Lighting Res. Technol. 2015; 0: 1-10.

16. Rad S, Abbasalizadeh S, Haghjo A, Sadagheyani M, Montaseri A, Rad J. Evaluation of the melatonin and oxidative stress markers level in serum of fertile women. Iran Reproductiv Medicine. 2015; 439-444.

17. Akamatsu S, Otsuki J, Fujii M, Enatsu N, Tsuji Y, Iwasaki T et al. The poor quality of women's sleep negatively influences fertilization rates in assisted reproductive technoogy. International Journal of Fertility and Sterility. 2016; 108(3):e120.

18. Park I, Sun H, Jeon G, Jo J, Kim S, Lee K. The more, the better? the impact of sleep on IVF outcomes. International Journal of Fertility and Sterility. 2013.

19. Eryılmaz Ö, Devran A, Sarikaya E, Aksakal F, Mollamahmutoğlu L, Cicek N. Melatonin improves the oocyte and embriyo in IVF patients with sleep disturbances, but does not improve the sleeping problems. Assisted Reproduction Technologies. 2011; 28:815-820. 